\title{
Feeding ecology of the Green-cheeked parakeet (Pyrrhura molinae) in dry forests in western Brazil
}

\author{
Ragusa-Netto, J.* \\ Departamento de Ciências Naturais, Campus Três Lagoas, Universidade Federal do Mato Grosso do Sul - UFMS, \\ CP 210, CEP 79600-000, Três Lagoas, MS, Brazil \\ *e-mail: forpus@ceul.ufms.br
}

Received June 29, 2005 - Accepted October 4, 2005 - Distributed May 31, 2007

(With 1 figure)

\begin{abstract}
The genus Pyrrhura includes small to medium-sized parakeets, which inhabit both low and dry alongside tall rainforests, mainly in South America. Pyrrhura molinae is still common, year round, in the markedly seasonal forests of western Brazil. This parakeet, as well as most Neotropical parrots, continues to be poorly understood. Hence, in the present study I examined their foraging ecology both in a highly deciduous and in a semi-deciduous forest in western Brazil. In addition, I assessed the relationship between food resource production (flowers and fruits), and the diet of this parakeet. Pyrrhura molinae exhibited a flexible diet consisting of 16 tree species, from which it consumed flowers (three species), seeds (three species), fruit pulp or aril (four species), and both pulp and seeds (six species). Parakeets consumed a wide array of fleshy fruits in the semi-deciduous forest, especially Cecropia pachystachya catkins. Conversely, in the highly deciduous forest they extensively foraged for figs ( $70 \%$ of the diet), in addition to nectar and seeds from dry fruits. Ficus calyptroceras, besides being abundant, bore fruits year round, and was substantially used by parakeets every month. Potentially, by exploiting a diverse set of plant food resources, and particularly due to the substantial use of figs, asynchronously produced, Pyrrhura molinae persists during the long dry season in the markedly seasonal forests of western Brazil.
\end{abstract}

Keywords: Pyrrhura molinae, Psittacidae, parrots, dry forests, canopy phenology.

\section{Ecologia alimentar da Tiriba-de-cara-suja (Pyrrhura molinae) em matas secas do oeste brasileiro}

\section{Resumo}

O gênero Pyrrhura é constituido de pequenos periquitos comuns tanto em matas secas quanto úmidas, sobretudo da América do Sul. Pyrrhura molinae ocorre durante o ano todo em florestas altamente sazonais do oeste brasileiro. Essa espécie, bem como a maioria dos psitacídeo, permanece pouco conhecida. Portanto, nesse estudo, foi examinada a ecologia alimentar de P. molinae em dois tipos de florestas secas (altamente decídua e semidecídua), do oeste brasileiro, bem como as relações entre a produção de flores frutos e a utilização desses recursos. Pyrrhura molinae exibiu uma dieta flexível em que utilizou recursos de 16 espécies arbóreas, sendo flores de três, sementes de outras três, a polpa dos frutos ou arilo de quatro espécies e, simultaneamente, a polpa e semente de seis espécies. Os periquitos consumiram principalmente frutos carnosos na floresta semidecídua, especialmente as infrutescências de Cecropia pachystachya. Por outro lado, na floresta altamente decídua, figos predominaram na dieta ( $70 \%$ dos registros de alimentação), somados ao néctar e sementes de frutos secos. Ficus calyptroceras, além de abundante produziu frutos o ano todo, que foram consumidos substancialmente pelos periquitos mês a mês. Presumivelmente, por explorar uma ampla variedade de recursos vegetais e subsistir, em grande parte, a base de figos produzidos assincronicamente, Pyrrhura molinae persiste à severa estação seca nas matas decíduas do oeste brasileiro.

Palavras-chave: Psittacidae, matas secas, fenologia, frugivoria, Pyrrhura molinae.

\section{Introduction}

Psittacines are prominent birds from Neotropical areas, which exhibit as common foraging features the use of seasonally available massive and ephemeral plant food resources (Bonadie and Bacon, 2000; Renton, 2001; RagusaNetto, 2004, 2005). While some species may be both habi- tat and foraging specialists, most of them are generalist, often exhibiting seasonal dietary shifts (Galetti, 1993; Ragusa-Netto, 2004; Ragusa-Netto and Fecchio, 2006), and movements within vegetation mosaics according to resource availability (Renton, 2001; Ragusa-Netto, 2005). 
Parakeets, the smaller members in this family, are conspicuous due to their frequent occurrence in large and mobile populations (del Hoyo et al., 1997; Sick, 1997). In addition, they exhibit a flexible diet, which may include diverse food items ranging from nectar to seeds (Roth, 1984; Pizo et al., 1995; Galetti, 1997; Ragusa-Netto, 2004; Ragusa-Netto and Fecchio, 2006). Therefore, they may play such ecological roles as seed predators (Janzen, 1981; Francisco et al., 2002; Ragusa-Netto, 2002b), and pollinators of tree species (Vicentini and Fischer, 1999; Coton, 2001; Ragusa-Netto, 2002a), although parakeets often exploit nectar, destructively damaging much of the flower crops. Hence, they potentially also act as pre-dispersal seed predators by reducing the fruit set (Cotton, 2001; Ragusa-Netto, 2002a, 2005).

The genus Pyrrhura includes a rich set of small to medium-sized species of parakeets, mostly confined to dense habitats in South America. Also, they inhabit dry as well as tall rainforests which occur from sea level up to 2000 m (Forshaw, 1989; del Hoyo et al., 1997). Like most Neotropical parrots, this genus continues to be poorly studied by ecologists with the exception of the P. frontalis (Pizo et al., 1995; Galetti, 1997; Kristosch and Marcondes-Machado, 2001), and to a lesser extent the $P$. picta, $P$. rhodogaster, and P. rupicola (Roth, 1984; Gilardi and Munn, 1998).

The Green-cheeked parakeet (Pyrrhura molinae) is still common in western Brazil and adjacent areas ( $E$ and NE Bolivia, NW Argentina), inhabiting dry, gallery and secondary forests (del Hoyo et al., 1997; Sick, 1997). In Brazil, P. molinae mostly occurs in the dry forests of western Mato Grosso and Mato Grosso do Sul (Sick, 1997). In spite of being common, no information is available on their feeding ecology, which may include contrasting patterns of food resource use in response to the pronounced seasonality of their major habitats (Galetti, 1993; Ragusa-Netto, 2004; Ragusa-Netto and Fecchio, 2006). Moreover, extensive areas inhabited by $P$. molinae have largely been cleared for pasture lands and field crops (del Hoyo et al., 1997). Hence, in this study I examined the $P$. molinae foraging ecology, both in a highly deciduous and in a semi-deciduous forest in western Brazil. Also, I analyzed the relationships between the seasonality of plant food resource production and the feeding activity of this parakeet.

\section{Methods}

\subsection{Study sites}

This study was carried out in a highly deciduous forest $\left(57^{\circ} 41^{\prime} \mathrm{W}\right.$ and $19^{\circ} 01^{\prime} \mathrm{S}$, elevation $\pm 130 \mathrm{~m}$, hereafter DF), and in a semi-deciduous forest (in the foothills of the Urucum mountain chain, $58^{\circ} 34^{\prime} \mathrm{W}$, $19^{\circ} 13^{\prime} \mathrm{S}$, elevation 150-200 m; hereafter SDF), both near the city of Corumbá, in the state of Mato Grosso do Sul. The DF site is part of a dry forest belt around Corumbá, which occurs on calcareous rich soil both in flat and hilly terrain. Although most of the area is covered by primary forest, there are disturbances caused by logging, resulting in clearings in the flat area. Mean annual temperature is $25{ }^{\circ} \mathrm{C}$. Annual rainfall is around $900 \mathrm{~mm}$, with $700 \mathrm{~mm}$ falling from November to March (wet season) and $200 \mathrm{~mm}$ from April to October (dry season). The vegetation includes deciduous trees with a canopy of 8-13 m. Species such as Aspidosperma pyrifolium (Apocynaceae), Miracrodruon urundeuva (Anacardiaceae) Tabebuia impetiginosa (Bignoniaceae), Ceiba boliviana (Bombacaceae), Cereus peruvianus (Cactaceae), Anadenanthera colubrina (LeguminoseaeMimosoideae), and Ficus calyptroceras (Moraceae) are among the commonest species (Ratter et al., 1988).

In the hilly terrain of Urucum there is a gradient of vegetation types, formed by semi-deciduous forest in the foothills, followed by low dry forest up to the timberline (700-800 m), and rock fields up to the top (approximately $1100 \mathrm{~m}$ ). In the undulated topography of the foothills, wet valleys are interspersed with dry peaks, and the forest canopy in this tract is $12-15 \mathrm{~m}$ tall, but emergent trees may reach 17-18 m. From June to September many tree species drop their leaves (mainly at peaks), while in the wet valleys some abundant species remain evergreen contributing to an evident semi-deciduous pattern. Annual rainfall is around $1100 \mathrm{~mm}$, most of which $(75-85 \%)$ occurs from October to March (wet season). During the wet season, average temperature is $26^{\circ} \mathrm{C}$, while during the dry season (April to September) on average $19{ }^{\circ} \mathrm{C}$ is recorded, and in the coldest months frosts may occur.

\subsection{Field procedures}

Flower and fruit production-At DF I established a $5 \mathrm{~km}$ transect for phenological observation alongside which (10 m in both sides) 50 individuals of F. calyptroceras $(\mathrm{DBH}>20 \mathrm{~cm})$ were marked with numbered aluminum tags and monitored every two weeks (from July 1999 to June 2000), for the presence of figs. Particularly, this sample was designed to assess fig phenology and their relationship with bird use (RagusaNetto, 2002b). The monthly surveys were carried out during two mornings, the first around day 10 and the second around day 25 . Fig abundance was visually estimated using $8 \times 30$ binoculars, and scored on a relative scale ranging from 0 (total absence) to 4 (crown full of figs).

The production of flowers and fruits was broadly examined at SDF. To select trees to sample flower and fruit abundance, 18 points were positioned (300 m apart from each other) along a $6 \mathrm{~km}$ permanent access trail. Eight points fell at hills, 10 at valleys. At each point the 15 nearest trees with diameters at breast height $(\mathrm{DBH})$ equal to or greater than $30 \mathrm{~cm}$ were numbered with aluminum tags. This criterion was adopted to assure the inclusion of canopy and emergent trees. Also, a tree was selected only if at least $80 \%$ of the crown could be observed from the forest floor. This random sample included 57 tree species whose importance for $P$. molinae was unknown. Individual crowns were monthly monitored (between day 20 and 25, from September 2000 to February 2002) for the presence of flowers and fruits with the aid of $8 \times 40$ binoculars. The abundance of flow- 
ers and fruits was also ranked on a relative scale ranging from total absence ( 0 ) to the full crown capacity (4) of a given phenophase. Thus, for a specific phenophase, the monthly index of resource abundance resulted from the sum of all abundance scores. Tree species were identified by comparison with samples in the herbarium at the Universidade Federal do Mato Grosso do Sul (Campus Corumbá) and following Lorenzi (1994, 1998).

Pyrrhura molinae food resources use- In order to examine the foraging activities of parakeets, I walked the trails used at both sites to sample food resource abundance. Monthly, I walked each of these trails for 30 hours, from 6 to 11 hours and from 15 to 18 hours, when parakeets were usually active. Then, whenever at least one feeding parakeet was detected, I recorded: a) tree species; b) food resource (flower or fruit); c) part eaten (petal; nectar; pulp or seed); d) the number of foraging parakeets; and e) the time and the date. Thus, a feeding record consisted of at least one parakeet feeding on a food resource, irrespective of time spent foraging and amount of food ingested. As the feeding records were used in correlation analyses, I used only the initial observation to assure independence among foraging samples. Moreover, most Neotropical parrots are opportunistic feeders and will include in their diet food items that make up relatively large, but only seasonally available, portions of biomass that serve as potential food. Hence, it is valid to use the initial observation of birds feeding on such resources, because it can be assumed that the birds are equally likely to be seen feeding on any abundantly available resource (Hejl et al., 1990). I assumed a conservative analysis, hence feeding records were correlated with food resource production regardless of the number of foraging parakeets. However, to clarify the consistence on the extension of food item use, the number of foraging parakeets is provided together with the proportion of every food item consumed by them (Table 1).

Table 1. Plant species, item eaten and habitat used by Pyrrhura molinae ( $\mathrm{N}=174$ feeding records, 80 at DF, and 94 at SDF), as well as parakeets recorded foraging. In parenthesis, percentage of feeding records according to sample size at each habitat type.

\begin{tabular}{|c|c|c|c|c|c|}
\hline Plant taxa & Item & Month & Habitat* & Feeding records $(\%)$ & Parakeets \\
\hline \multicolumn{6}{|l|}{ Anacardiaceae } \\
\hline Myracrodruon urundeuva & seed & Jul, Aug & $\mathrm{DF}$ & $4(8)$ & 40 \\
\hline \multicolumn{6}{|l|}{ Araliaceae } \\
\hline Schefflera morototoni & pulp & Oct & SDF & $1(1.5)$ & 8 \\
\hline \multicolumn{6}{|l|}{ Bignoneaceae } \\
\hline Tabebuia impetiginosa & nectar & Jun, Jul & $\mathrm{DF}$ & $6(11)$ & 64 \\
\hline \multicolumn{6}{|l|}{ Bombacaceae } \\
\hline Eriotheca roseorum & seed & Sept & SDF & $3(7)$ & 17 \\
\hline \multicolumn{6}{|l|}{ Burseraceae } \\
\hline Commiphora leptophloeos & seed, aril & Feb & DF & $1(1.5)$ & 18 \\
\hline Protium heptaphyllum & aril & Oct, Nov, Dec & SDF & $8(18)$ & 76 \\
\hline \multicolumn{6}{|l|}{ Cactaceae } \\
\hline Cereus peruvianus & seed, pulp & Nov & $\mathrm{DF}$ & $2(3)$ & 13 \\
\hline \multicolumn{6}{|l|}{ Cecropiaceae } \\
\hline Cecropia pachystachya & seed, pulp & Oct-March & SDF & $18(40)$ & 202 \\
\hline \multicolumn{6}{|l|}{ Flacourtiaceae } \\
\hline Casearia gossypiosperma & seed & Sept & $\mathrm{DF}$ & $1(1.5)$ & 26 \\
\hline \multicolumn{6}{|l|}{ Leguminosae } \\
\hline Erythrina dominguezii & nectar & Sept & DF, SDF & $3(4 ; 6)$ & 30 \\
\hline \multicolumn{6}{|l|}{ Meliaceae } \\
\hline Guarea guidonia & aril & Nov & SDF & $1.5(3)$ & 9 \\
\hline \multicolumn{6}{|l|}{ Moraceae } \\
\hline Ficus calyptroceras & seed, pulp & all year & DF, SDF & $41(70 ; 2.5)$ & 633 \\
\hline Macloura tinctoria & seed, pulp & Nov, Dec & SDF & $3(5)$ & 9 \\
\hline \multicolumn{6}{|l|}{ Sapindaceae } \\
\hline Dilodendron bippinnatum & aril & Nov & SDF & $6(14)$ & 19 \\
\hline \multicolumn{6}{|l|}{ Sapotaceae } \\
\hline Pouteria torta & flower & Sept & SDF & $1(3)$ & 14 \\
\hline \multicolumn{6}{|l|}{ Ulmaceae } \\
\hline Trema micrantha & seed, pulp & May & $\mathrm{DF}$ & $0.5(1)$ & 12 \\
\hline
\end{tabular}

*Habitat type: $\mathrm{DF}=$ Deciduous forest; and SDF = semi-deciduous forest. 


\subsection{Analyses}

To evaluate the relationship between parakeet foraging activity and plant resource production, the Spearman correlation was used. The monthly indices of resource abundance were taken as variables and correlated with parakeet foraging activity, which corresponded to the monthly percentage of feeding records.

\section{Results}

\subsection{Flower and fruit production}

In the twelve months of observations at DF, eight trees produced no figs, 28 bore figs once and 14 bore figs twice. Among the trees that failed to fruit, only one was a large tree $(\mathrm{DBH}>60 \mathrm{~cm})$, while all those trees which bore figs twice were among the larger ones (DBH between $60-120 \mathrm{~cm}$ ). The monthly number of trees bearing ripe figs ranged from two (September and December 1999), to seven (January 2000, Figure 1), so that a similar proportion of trees bore figs in the dry and wet seasons (48 and 52\%, respectively, Figure 1). As most of the time $6-10 \%$ of the trees were fruiting, an aseasonal fruiting pattern was evident. The two major reductions in the number of fruiting trees were recorded in September (end of the dry season) and December (middle of the wet season). These were among the driest and wettest months, respectively (Figure 1).

At SDF the 57 tree species from the phenology sample belong to 25 families. From April to July, up to 10 species flowered, while from August to October, 22 did so, comprising a sharp flowering peak. Such peak arose mainly from flowering of Protium heptaphyllum, Pouteria torta, Astronium fraxinifolium, and Erythrina dominguezii.

Fruit production was also seasonal, so that a slight peak was recorded in the middle of the dry season, whereas a very pronounced fruiting peak occurred in the transition from the dry to the wet season (Figure 1). The first peak arose mostly from fruiting in Anadenanthera colubrina, Cedrela fissilis, Caesalpina peltophoroides, and Dipteryx alata. In this period 17 species were fruiting, of which only $47 \%$ produced fleshy fruits. On the other hand, the major peak of fruit production resulted from fruiting of abundant species such as Protium heptaphyllum, Guarea guidonia, Pouteria torta, and Spondias lutea. This fruiting peak included up to 20 species, most of which $(70 \%)$ bore fleshy fruits.

\subsection{Pyrrhura molinae food resources use}

Parakeets foraged on 16 tree species from 14 families, in a total of 174 feeding records, 80 of which at DF and the rest at SDF. Parakeets used eight species at DF, while 10 were used at SDF. Only two species (flowers from Erytrina dominguezii, and figs from Ficus calyptroceras) were used in both habitats (Table 1), although several other species were common to both sites. Parakeets exhibit a contrasting foraging pattern, so that most species were moderately used, while they extensively foraged
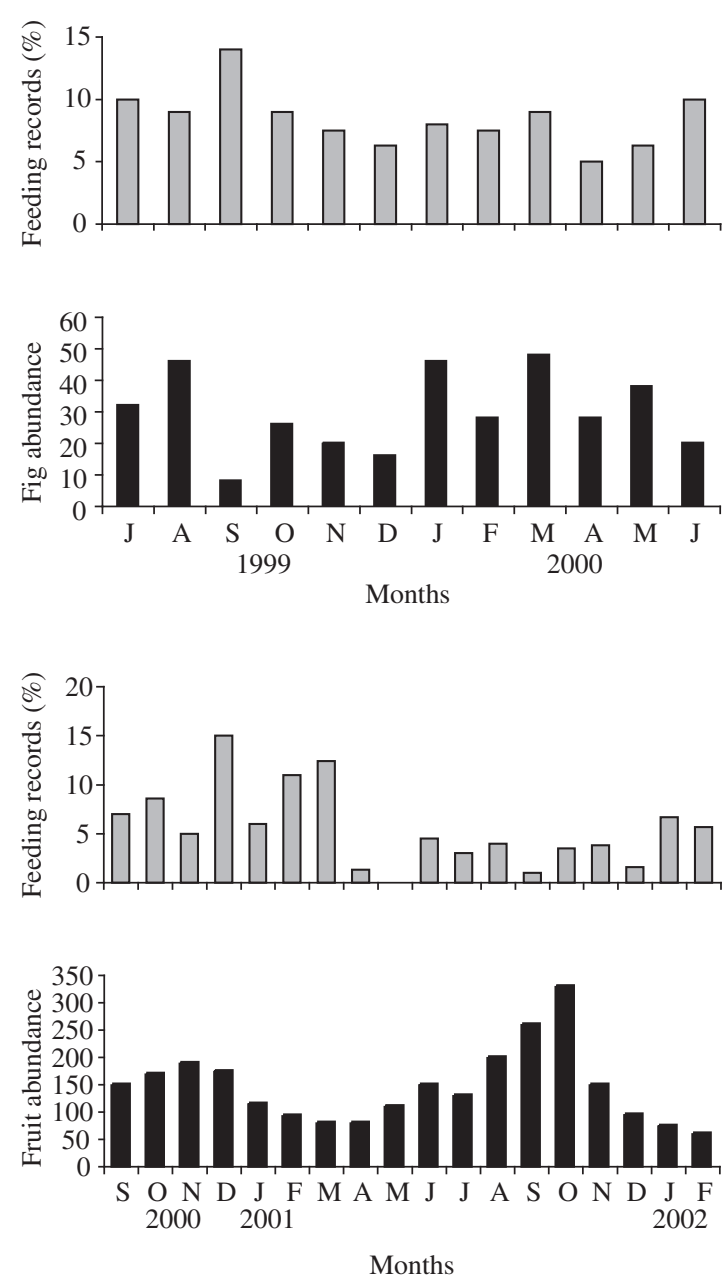

Figure 1. Above: the monthly pattern of fig abundance and foraging activity of Pyrrhura molinae in the highly dry forest. Below: the fruiting pattern in the semi-deciduous forest as well as the foraging activity of P. molinae.

on few food plants (Table 1). They foraged on flowers from three species, mainly from the middle to the late dry season. In fact flowers formed $10 \%$ of their diet, specially the nectar from Tabebuia impetiginosa at DF. At this site trees bore large flower crops, particularly in July 1999, which parakeets often consumed (Table 1). Also during the dry season, parakeets ate the seeds from other three wind dispersed species (suggested by their winged or plumed diaspores, Table 1). From four species with fleshy fruits, parakeets consumed the pulp or aril, although only two of them were regularly used (Protium heptaphyllum, and Dilodendron bippinnatum), both at SDF. With the exception of Schefflera morototoni, the species from which they exploited the pulp or aril had large seeds (Table 1). Parakeets ate both the pulp and small seeds from six species. Among them were Ficus calyptroceras, and Cecropia pachystachya, which, if grouped, comprised the bulk of P. molinae diet (59\% of 
feeding records, Table 1). Figures were common at DF, and scarce at SDF, while an inverse pattern of abundance was clear for C. pachystachya. Therefore, analyzing the use of these resources at each habitat type, strong differences emerged. At SDF, C. pachystachya comprised $40 \%$ of the feeding records, mostly during rains; however no consumption occurred at DF. At this site, Ficus calyptroceras was both extraordinarily and year-round used (70\% of feeding records); while at SDF parakeets foraged for figs only twice (Table 1).

In order to analyze the relationship between plant food resource availability and parakeet foraging activity, I correlated the monthly fig production with parakeet foraging activity at DF, since by far, this was their major food resource in this habitat type. Also, I correlated only fruit production with parakeet foraging activity, at SDF, due to the reduced use of other food items in this forest. In both cases, parakeet foraging activity was unrelated with fig or fruit availability $(r s=0.37, \mathrm{P}>0.40$; and $r s=0.21, \mathrm{P}>0.60$, respectively, Figure 1).

\section{Discussion}

\subsection{Flower and fruit production}

Although an increase or a reduction in the number of fruiting trees was observed in some months, the fruiting pattern in Ficus calyptroceras was clearly asynchronous. Every month trees initiated fruit crops, as well as bore ripe figs, as did other Ficus species studied elsewhere in the tropical forests (Foster, 1982; Milton et al., 1982; Leighton and Leighton, 1983; van Shaik, 1986; Corlett, 1987; Windsor et al., 1989). In spite of the fact that $F$. calyptroceras occurs in a highly deciduous forest, where the dry season is severe and heavy rainfall is concentrated in a few months, in both seasons a similar proportion of trees bore figs. Moreover, trees bore figs at intervals shorter than a year and in some cases shorter than six months, which presumably influenced fruiting asynchrony in addition to their breeding strategies (Milton et al. 1982).

The marked flowering and fruiting pattern in the SDF were potentially conformed to rainfall seasonality, since in the dry forests massive flowering and fruiting usually occur near the onset of the rains (Frankie et al., 1974; Bullock and Solis-Magallanes, 1990; van Schaik et al., 1993; Funch et al., 2002). A substantial fruit production after the early rains is presumably related to the short period with wet conditions, in forests often subjected to a severe dry season. Then, both seed germination and seedling establishment usually take place in the beginning of the wet season to avoid unfavorable conditions and consequently a higher risk of mortality during the late wet season (van Schaik et al., 1993). Seedlings from many species that fruited during the early wet season, especially those from Protium heptaphyllum, formed a carpet at some places of the forest floor in the middle of the wet season (pers. obs.).

\subsection{Pyrrhura molinae food resources use}

Pyrrhura molinae exhibited a generalist diet, since besides exploiting several tree species, it used a variety of food items, from nectar to pure seeds, similarly to other species from this genus studied elsewhere in richer floras (Roth, 1984; Pizo et al., 1995; Galetti, 1997; Kristosch and Marcondes-Machado, 2001). While in the Atlantic forest, $P$. frontalis foraged on 14 species at lowlands (Galetti, 1997), it used 28 at mid elevation (Pizo et al., 1995), and 21 at highlands, ten of which were exotic (Kristosch and Marcondes-Machado, 2001). In the Brazilian Amazonian $P$. picta consumed 28 species, while $P$. rhodogaster exploited 16 (Roth, 1984). Other common features of feeding habits in Pyrrhura is the enhanced use of fleshy fruits, in addition to the extensive consumption of few, but, massively available food resources, in contrast with the moderated use of a wide set of plant species. However, the major food items for every studied species differed markedly. Moreover, the same species exhibited different food habits in diverse areas. This was also the case for $P$. molinae at the studied sites, which are still connected. In the Atlantic forest Pyrrhura frontalis mostly used Cecropia catkins (Pizo et al.,1995), similarly to P. molinae at SDF. Nevertheless, at different altitudes $P$. frontalis mostly foraged for Lauraceae fruits or Podocarpus seeds (Galetti, 1997; Kristosch and Marcondes-Machado, 2001; respectively). In the case of $P$. molinae, their major foods were very contrasting with respect to their occurrence at each site. Cecropia pachystachya was common at SDF, however virtually absent from the DF. On the other hand, only two Ficus calyptroceras were within the phenology sample in the SDF (6 km-trail), while 50 fig trees were sampled in the DF (5 km-trail). Fruits from both species were massively available, as the major resources used by the other species of Pyrrhura. Such varied use of plant resources at neighboring areas evidences the flexibility of this group, which is common throughout a wide range of seasonal forests.

Ficus calyptroceras bore figs asynchronously, which were consumed year round. Furthermore, P. molinae similarly foraged for figs in the dry and rainy season, in addition to their increased fig use at DF (RagusaNetto, 2002b). Hence, during the rains when potentially, at DF, fruits were plentiful, figs continued to be important for them, suggesting that fig abundance was not the only or the major cause for their pronounced use. Several fig species exhibit high nutritional quality, which may be added by the nutrients from their small seeds (Wendeln et al., 2000), crushed and digested by parakeets (Janzen, 1981). Such peculiarities, coupled with the abundance of $F$. calyptroceras, potentially explain the importance of figs for $P$. molinae, as well as their average foraging activity at DF, in comparison with that recorded at SDF. At this site, the most used resource, Cecropia pachystachya, bore massive fruit crop mainly from December to March, when general fruit availability was declining. Also, P. molinae moderately used other species (Protium heptaphyllum, Pouteria torta, 
and Guarea guidonia) important for the fruiting pattern. Therefore, $P$. molinae seldom foraged at SDF when such fruits were abundant. Contrasting to this, other parakeet (Brotogeris chiriri), also studied at this site, were highly abundant while extensively foraged on $P$. heptaphyllum fruits (Ragusa-Netto, submitted), Moreover, pronounced changes of abundance is usual for parrots which mostly rely on seasonal food resources (Bonadie and Bacon, 2000; Wirminghaus et al., 2001, 2002; Ragusa-Netto, 2004, 2005, in press). In this respect, the scattered fig availability at DF, and moderated use of abundant fruits at SDF may, at least partly, cause the absence of relationship between foraging activity and resource availability.

The dry season at DF lasted eight months with much reduced rainfall (150 mm, Ragusa-Netto, 2002b). However, $P$. molinae remained in the area mostly foraging for figs. In many tropical areas figs have been recorded as keystone resources for favoring the persistence of frugivores during periods of famine (Terborgh, 1986; Lambert and Marshal, 1991). The substantial use of figs by $P$. molinae clarify the importance of this abundant and aseasonal resource in the highly seasonal forests of western Brazil. Unfortunately these habitats are undergoing a severe deforestation process, hence, further conservation plans may consider fig rich dry forests for the maintenance of large populations of $P$. molinae and other frugivorous birds as well (Ragusa-Netto, 2002b).

Acknowledgments - I am grateful to Vanda Lúcia Ferreira, Rosilene Rodrigues-Silva, Gesner Batista Ramos, Marivânia Moraes, Michele Lima and Vanessa Padilha for field assistance. Rosilene Rodrigues-Silva was also helpful in the identification of many tree species. The constructive comments of an anonymous reviewer improved the manuscript. Financial support was provided by CNPq and PROPP/UFMS.

\section{References}

BONADIE, WA. and BACON, PR., 2000. Year-round utilization of fragmented palm swamp forest by Red-bellied macaws (Ara manilata) and Orange-winged parrots (Amazona amazonica) in the Nariva Swamp (Trinidad). Biol. Conserv., vol. 95 , p. 1-5.

BULLOCK, SH. and SOLIS-MAGALLANES. JA., 1990. Phenology of canopy trees of a tropical deciduous forest in Mexico. Biotropica, vol. 22, p. 22-35.

CORLETT, RT., 1987. The phenology of Ficus fistulosa in Singapore. Biotropica, vol. 19, p. 122-124.

COTTON, PA., 2001. The behavior and interactions of birds visiting Erythrina fusca flowers in the Colombian Amazon. Biotropica, vol. 33, p. 662-669.

DEL HOYO, J., ELLIOT, A. and SARGATAL, J., 1997. Handbook of the birds of the world, vol 4. Sangrouse to Cuckoos. Lynx, Barcelona.

FORSHAW, JM., 1989. Parrots of the world, 3 rd ed. Melbourne: Lansdowne Editions.

FOSTER, RB., 1982. The seasonal rhythms of fruitfall on Barro Colorado Island. In Leigh, EG., Rand and Windsor, AS. (eds), The Ecology of a Tropical Forest. Smithson. Inst. Press, Washington, D.C.
FRANCISCO, MR., LUNARDI, VO. and GALETTI, M., 2002. Massive seed predation of Pseudobombax grandiflorum (Bombacaceae) by parakeets Brotogeris versicolurus (Psittacidae) in a forest fragment in Brazil. Biotropica, vol. 34, p. 613-615.

FRANKIE, GW., BAKER, HG. and OPLER, PA., 1974. Comparative phenological studies of trees in tropical wet and dry forests in the lowlands of Costa Rica. J. Ecol., vol. 62, p. 881-919.

FUNCH, LS., FUNCH, R. and BARROSO, GM., 2002. Phenology of gallery and montane forest in the Chapada Diamantina, Bahia, Brazil. Biotropica, vol. 34, p. 40-50.

GALETTI, M., 1993. Diet of scaly-headed parrot (Pionus maximiliani) in a semi-deciduous forest in southeastern Brazil. Biotropica, vol. 25, p. 419-425.

GALETTI, M., 1997. Seasonal abundance and feeding ecology of parrots and parakeets in a lowland Atlantic Forest Brazil. Ararajuba, vol. 5, p. 115-126.

GILARDI, JD. and MUNN, CA., 1998. Patterns of activity, flocking, and habitat use in parrots of the Peruvian Amazon. Condor, vol. 100, p. 641-653.

HEJL, SJ., VERNER, J. and BELL, W., 1990. Sequential versus initial observations in studies of avian foraging. Stud. Av. Biol., vol. 13 , p. 166-173.

JANZEN, D., 1981. Ficus ovalis seed predation by Orangechinned Parakeet (Brotogeris jugularis) in Costa Rica. Auk, 1981, vol. 98, p. 841-844.

KRISTOSCH and MARCONDES-MACHADO, 2001. Diet and feeding ecology of the Reddish-bellied parakeet (Pyrrhura frontalis) in an araucaria forest in Southeastern Brazil. Ornith. Neotr., vol. 12, p. 1-9.

LAMBERT, F. and MARSHAL, AG., 1991. Keystone characteristics of bird-dispersed Ficus in a Malaysian lowland rain forest. J. Ecol., vol. 79, p. 793-809.

LEIGHTON, M. and LEIGHTON, D., 1983. Vertebrate responses to fruiting seasonality within a Bornean rain forest. In SUTTON, SL., WHITMORE, TC. and CHADWICK, AC. (eds.). Tropical Rain Forest: Ecology and Management. Blackwell Scientific Publications, Oxford, England.

LORENZI, A., 1994. Árvores Brasileiras. Manual de identificação e cultivo de plantas arbóreas do Brasil. Editora Plantarum, Nova Odessa, vol. 1, 320 p.

LORENZI, A., 1998. Árvores Brasileiras. Manual de identificação e cultivo de plantas arbóreas do Brasil. Editora Plantarum, Nova Odessa, vol. 2, 320 p.

MILTON, K., WINDSOR, DM., MORRISON, DW. and ESTRIBI, MA., 1982. Fruiting phenologies of two tropical Ficus species. Ecology, vol. 63, p. 752-762.

PIZO, MA., SIMÃO, I. and GALETTI, M., 1995. Diet and flock size of sympatric parrots in the Atlantic Florest of Brazil. Orn. Neot., vol. 6, p. 87-95.

RAGUSA-NETTO, J., 2002a, Exploitation of Erythrina dominguezii Hassl. (Fabaceae) nectar by perching birds in a dry forest in western Brazil. Braz. J. Biol., vol. 62, p. 877-883.

RAGUSA-NETTO, J., 2002b, Fruiting phenology and consumption by birds in Ficus calyptroceras (Miq.) Miq. (Moraceae). Braz. J. Biol., vol. 62, p. 339-346. 
RAGUSA-NETTO, J., 2004. Flowers, fruits and the abundance of the Yellow-chevroned parakeet (Brotogeris chiriri) at a gallery forest in the South Pantanal (Brazil). Braz. J. Biol., vol. 64, p. $867-877$.

RAGUSA-NETTO, J., 2005. Extensive consumption of Tabebuia aurea (Manso) Benth. and Hook. (Bignoniaceae) nectar by parrots in a tecoma savanna in the South Pantanal (Brazil). Braz. J. Biol., vol. 65, p. 339-344.

RAGUSA-NETTO, J., 2006. Arils and the abundance of the Yellow-chevroned parakeet (Brotogeris chiriri) in a dry forest in western Brazil. Stud. Neotr. F. Env., submitted: Outubro de 2006.

RAGUSA-NETTO, J., 2007. Nectar, fleshy fruits and the abundance of parrots at a gallery forest in the Southern Pantanal (Brazil). Stud. Neotr. F. Env., in press, vol. 42.

RAGUSA-NETTO, J. and FECCHIO, A., 2006. Plant food resources and the diet of a parrot community at a gallery forest in the Southern Pantanal, Brazil. Braz. J. Biol., vol. 66, p. 1021-1032.

RATTER, JA., POTT, A., POTT, VJ., CUNHA, CN. and HARIDASAN, M., 1988. Observation on wood vegetation types in the Pantanal at Corumbá, Brazil. N. RBG. Edinb., vol. 3, p. 503-525.

RENTON, K., 2001. Lilac-crowned parrot diet and food resource availability: resource tracking by a parrot seed predator. Condor, vol. 103, p. 62-69.

ROTH, P., 1984. Repartição do habitat entre psitacídeos simpátricos no sul da Amazônia. Acta Amaz., vol. 14, p. 175-221.
SICK, H., 1997. Ornitologia Brasileira. Nova Fronteira, Rio de Janeiro, $912 \mathrm{p}$.

TERBORGH, J., 1986. Keystone plant resources in the tropical forest. In SOULÉ, M. (ed), Conservation Biology. Sinauer, Sunderland, Massachussets.

van SCHAIK, CP., 1986. Phenological changes in a Sumatran rain forest. J. Trop. Ecol., vol. 2, p. 327-347.

van SCHAIK, CP., TERBORGH, JW. and WRIGHT, SJ., 1993. The phenology of tropical forests, adaptive significance, and consequences for primary consumers. Ann. Rev. Ecol. Syst., vol. 24, p. 353-377.

VICENTINI, A. and FISCHER, EA., 1999. Pollination of Moronobea coccinea (Cluseaceae) by the Golden-winged Parakeet in Central Amazonia. Biotropica, vol. 31, p. 682-696.

WENDELN, MC., RUNKLE, JR. and KALKO, EKV., 2000. Nutritional values of 14 fig species and bat preferences in Panama. Biotropica, vol. 32, p. 489-501.

WINDSOR, DM., MORRISON, DW., ESTRIBI, MA. and DE LEON, B., 1989. Phenology of fruit and leaf production by strangler figs on Barro Colorado Island, Panama. Experientia, vol. 45, p. 647-653.

WIRMINGHAUS JO., DOWNS CT., SYMES CT. and PERRIN MR., 2001. Abundance and activity patterns of the Cape Parrot (Poicephalus robustus) in two afromontane forests in South Africa. African Zool., vol. 36, p. 71-77.

WIRMINGHAUS JO., DOWNS CT., SYMES CT. and PERRIN MR., 2002. Diet of the cape parrot, Poicephalus robustus, in Afromontane forrests in Kwazulu-Natal, South Africa. Ostrich, vol. 73 , p. 20-25. 
